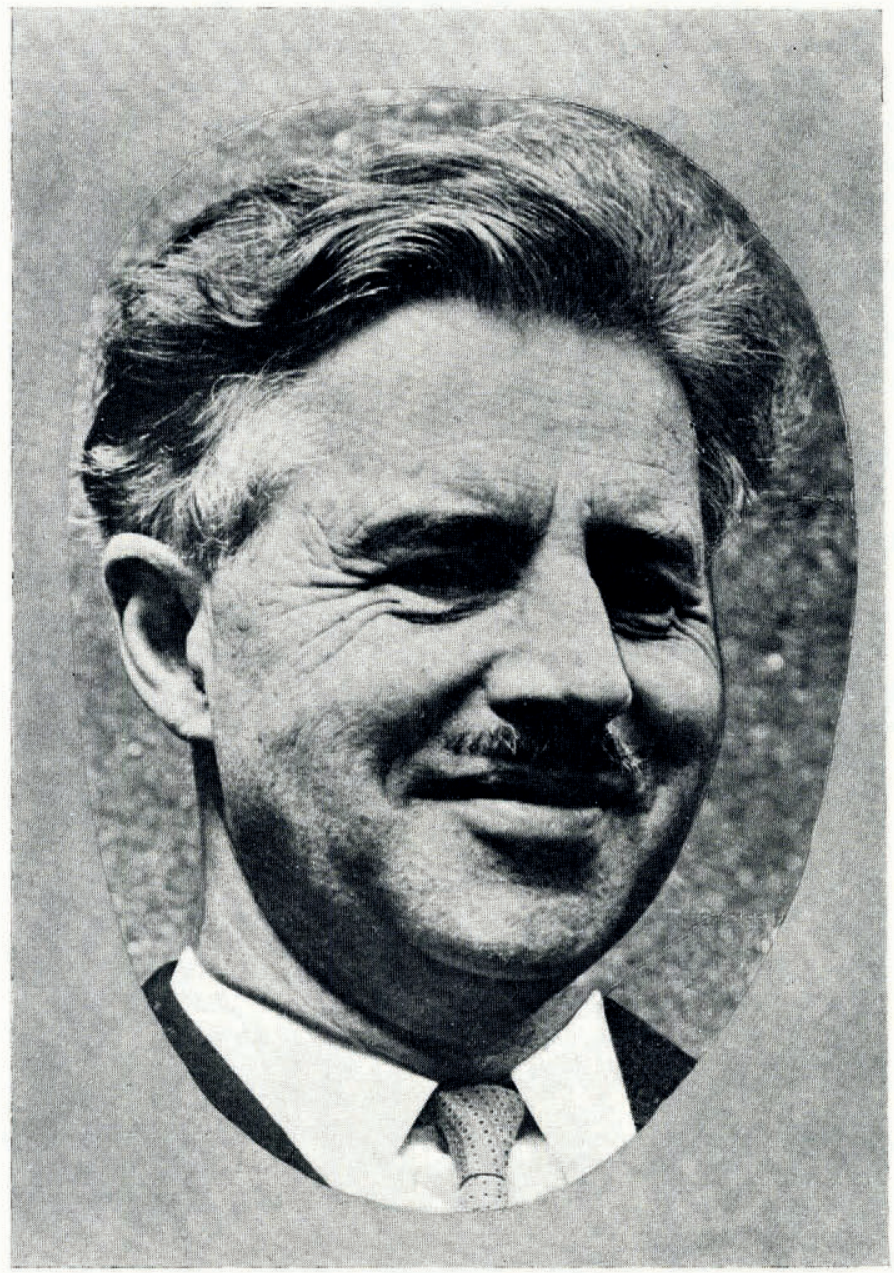

\title{
KAARE STRØM-I902-I967
}

KaAre Strøm started his academic studies with specialization in fresh-water biology. The first papers, out of more than a hundred, were published as early as 1920 , and when he obtained his Doctor's degree at the University of Oslo in 1927 , he was already an experienced scientist. Later, he extended his interests with more general studies of physics, chemistry, geology and particularly geomorphology which, together with biology, were used in his thorough investigations of lakes, or limnology in its full sense.

From r 93 I he was attached to the University of Oslo, and his appointment in 1939 as Dosent of Limnology implied the establishment of limnology as a University subject in Norway. From 1948 to 1962 he held a Chair of Geography, teaching both limnology and geomorphology, his appointment being changed in 1962 to a Chair of Limnology only.

In later years the main part of his scientific production was concerned with the physical and chemical properties of lakes, and most of his many students have been engaged in research within these topics. Since he was one of the pioneers of limnology, his work has been of fundamental importance for the international development of this science, and he was highly 
esteemed among his colleagues all over the world. Particularly well-known are his studies on thermics and of stagnant water in the bottom of lakes as well as in the depth of fjords, the so-called land-locked waters.

On the basis of his experience with sediments accumulated in anaerobic environments he concluded that the widely distributed black shales, of alum shale type, from older geological periods had been deposited in seas where the bottom water was not renewed due to incompleteness of the vertical circulation. Later, trapped sea-water in the bottom of certain lakes below the highest marine limit was studied by him and some of his students.

Professor Strøm always stressed that "every lake is a world of its own", with its chemical and physical conditions and with its flora and fauna, but at the same time that "every lake is a part of the landscape". The inclusion of the geomorphology of the lake basins in his limnological studies soon resulted in studies of other aspects of geomorphology too. Naturally his interest was in the first place directed towards the geomorphological problems of mountain areas, particularly the forms resulting from local glaciation and the interpretation of Norway's wide upland surfaces. The work in the mountains aroused his interest in snow and ice, and he was absorbed by modern views as to the mode of deglaciation, in particular the dead ice down-wastage in the central parts of Norway.

Professor Strøm's wide scientific interests were of great importance in his academic work, particularly during the years he was responsible for the physical part of geography. Many students will remember his exciting demonstrations and discussions on different landforms, stressing how processes work together and how the elements are parts of a connected whole.

With his clear mind Strøm had a pronounced analytical power and he was nearly always able to see at once the interconnection between details. He was worried when specialization resulted in isolation as between disciplines which are closely related and mutually necessary. For him the increasing subdivision of science was not only unnatural but meaningless and dangerous. He clearly saw the interdependence between the different processes in Nature, and wished to establish a synthesis of the geo-sciences.

Professor Strøm's personal interests stretched far beyond science, comprising architecture, the arts, literature, politics, cultural and social problems, history, defence and peace problems, including the responsibility of scientists. He was also an expert in heraldry.

Kaare Strøm was of a shy disposition, working in his own quiet way, but he had a considerable influence upon matters and persons with whom he came into close contact.

J. GJEssing 